\title{
UMA DEMOCRACIA EM COLAPSO: O ESGOTAMENTO DO POSSÍVEL E A EXPERIÊNCIA ÉTICA
}

\author{
Édio RANIERE ${ }^{1}$ \\ Cleci MARASCHIN ${ }^{2}$
}

\begin{abstract}
Resumo
Vivemos no Brasil uma espécie de descrédito com relação a algumas das nossas experiências coletivas. A promulgação da Constituição Cidadã em 1988 levou uma grande parcela da nossa população acreditar que havíamos construído um patamar mínimo de institucionalidade, a partir do qual novas potências poderiam ser efetuadas. Contudo, em menos de trinta anos assistimos essa crença ser desconstruída. Concomitantemente ao cenário nacional, parece estar em curso, em muitos países, uma onda conservadora que vem colocando em xeque o próprio regime democrático. Nessa circunstância uma irremediável questão se impõe: a democracia estaria entrando em colapso? Para além da perplexidade, paralisia e angústia, muitas vezes experienciadas em momentos de desmonte, alguns pensadores e cientistas afirmam que são justamente os momentos de breakdown, como o que estamos atravessando, que se apresentam grávidos de virtuais. Virtuais, pois não se trata de buscar pelo possível da possibilidade - o qual previamente se coloca à disposição como escolha - mas se perguntar pelo possível da potência. A questão pode então ser reposicionada: em que medida as insurreições que estamos vivendo criam condições de possibilidade para que a experiência ética seja tomada em primeiro plano, e não mais a reboque do projeto/modelo político a ser atingido, escolhido, selecionado? Assim, a aposta deste texto é a de permitir passagem a uma vida que vem - aberta pelo colapso e pelas insurreições em curso. Ou seja, a de problematizar o corpo democrático fazendo ressoar potências de intercessores como Gilles Deleuze, Francisco Varela e Jacques Rancière.
\end{abstract}

\begin{abstract}
We live in Brazil a kind of discredit in relation to some of our collective experiences. The enactment of the Citizen Constitution in 1988 led a large part of our population to believe that we had built a minimum level of institutionality, from which new powers could be realized. However, in less than thirty years we have seen this belief deconstructed. Concomitantly with the national scenario, in many countries, a conservative wave seems to be under way, which has put the democratic regime itself in check. In this circumstance an irremediable question arises: would democracy be collapsing? In addition to the perplexity, paralysis and anguish, often experienced in moments of dismantling, some thinkers and scientists affirm that it is precisely the breakdown moments, such as the one we are experiencing, that are pregnant with virtual ones. Virtuals, for it is not a matter of seeking for the possible of possibility - which is previously available as a choice - but to ask about the potential of power. The question can then be repositioned: to what extent do the insurrections we are experiencing create conditions of possibility for ethical experience to be taken in the foreground, and no longer in the wake of the political project / model to be reached, chosen, selected? Thus, the bet of this text is to allow passage to a life that comes - opened by the collapse and insurrections in progress. That is, to problematize the democratic body by resonating powers of intercessors like Gilles Deleuze, Francisco Varela and Jacques Rancière
\end{abstract}

\section{O COLAPSO}

05 de outubro de 1988. Num solitário murmúrio ela observa a certidão de nascimento estendida sobre a mesa: 05 de outubro de 1988. Suavemente perpassa a ponta dos dedos sobre o documento. Demora-se sob o gesto - vinte e oito anos, angustiada sussurra para si mesma, tenho

\footnotetext{
${ }^{1}$ E-mail: edioraniere@gmail.com

${ }^{2}$ E-mail: cleci.maraschin@gmail.com

Revista do Instituto Histórico e Geográfico do Pará (IHGP), (ISSN: 2359-0831 - online), Belém, v. 04, n. 02, p. 67-87, jul./dez. 2017.
} 
agora vinte e oito anos - até que pega de surpresa por um frio fantasma interrompe o pensamento: não consigo lembrar ... de novo isso. Que coisa ... não consigo lembrar de novo. Por que isso está acontecendo comigo? Será que estou doente? Onde foi que deixei aquele maldito atestado de óbito? Estava com ele aqui ... quando foi? Ontem! ontem mesmo. Que merda, sempre a mesma coisa. Acho que vou consultar um médico ... Por que, diabos, não consigo lembrar a idade que minha mãe tinha? Talvez na sala - procurando - Não! Não está. Na cama. Será que deixei na biblioteca? Após uma breve pesquisa ela encontra o documento servindo como marcador de página num livro de Scott Fitzgerald. A certidão informa 31 de março de 1964 como data de falecimento. Dezoito anos, então era isso, ela tinha apenas dezoito anos. Minha mãe morreu com dezoito anos - repetindo a idade como um mantra. Se percebe vivendo dez anos a mais que sua mãe. Apesar de não compreender bem o turbilhão de sensações que lhe atravessam o corpo algo a incomoda profundamente nesta diferença. Depois de alguns minutos devaneando sobre possíveis causas que pudessem justificar o incômodo, ela percebe no livro de Fitzgerald - Crack-Up - ainda aberto em seu colo o conto marcado pelo atestado de óbito de Dona Kratia da Silva: O Colapso. Um agudo fascínio perpassa seus olhos:

Claro que toda vida é um processo de ruptura, mas os golpes que realizam o lado dramático dessa obra de decomposição, os grandes golpes repentinos que surgem ou parecem surgir do exterior, aqueles dos quais nos lembramos e aos quais culpamos por tudo e que, em momentos de fraqueza, contamos a nossos amigos, não mostram o seu efeito logo de cara. Há uma outra espécie de golpe que vem de dentro, que não sentimos até ser tarde demais para fazer qualquer coisa, até percebermos de forma decisiva que em alguns aspectos nunca mais seremos os mesmos. A primeira espécie de ruptura parece acontecer rapidamente; a segunda acontece quase sem notarmos, mas é com certeza percebida de súbito. (p. 9)

Envolta numa espécie de transe arremessa o livro, cuja queda - sons e estilhaçamentos colocam-na de pé, bem diante da mesa onde o retorno de Crack-Up fizeraespedaçarum copo. Curiosamente o livro caíra aberto nas mesmas páginas, oferecendo aos olhos nervosos de Demokratia.br, novamente, O Colapso. Bem ao lado de Crack-up estava sua certidão de nascimento. Demokratia.br da Silva, nascida no Brasil em 05 de outubro de 1988. Uma forte vertigem toma conta do corpo de nossa protagonista, o desmaio dura breves minutos. Quando volta a si, assustada, procura vários médicos. Faz exames, recebe diagnósticos e indicações de Revista do Instituto Histórico e Geográfico do Pará (IHGP), (ISSN: 2359-0831 - online), Belém, v. 04, n. 02, p. 67-87, jul./dez. 2017. 
tratamento. Durante 180 dias Demokratia.br sente-se muito mau: vômitos, tonturas, febre. O que está acontecendo comigo? Muito assustada, sem saber a quem recorrer, num espasmo de desespero, buscando esquecer de si, acessa as redes sociais:

MACHADO - Rapaz, a solução mais fácil era botar o Michel

JUCÁ - Só o Renan [Calheiros] que está contra essa porra. 'Porque não gosta do Michel, porque o Michel é Cunha'. Gente, esquece o Eduardo Cunha, o Cunha está morto, porra.

MACHADO - É um acordo, botar o Michel, num grande acordo nacional.

JUCÁ - Com o Supremo, com tudo.

MACHADO - Com tudo, aí parava tudo.

JUCÁ - É. Delimitava onde está, pronto...(Folha de São Paulo, 2016)

Demokratia.br sente dificuldades para continuar lendo o diálogo, uma idéia estranha toma

conta dela. Por vezes tem a impressão de que está diminuindo de tamanho. Ao invés de médico será que deveria procurar um psicólogo? O que está acontecendo comigo? Breve soluço, algumas

lágrimas e vem o esforço para concentrar-se novamente nas postagens:

o movimento Escola Sem Partido que organiza eventos, produz conteúdo digital divulgado em seu sítio eletrônico etc. e patrocina ações legislativas que estimulam a coação, o constrangimento e a censura aos professores de História em todo o território nacional. Já temos registro de casos de professores que sofreram e ainda sofrem esse tipo de ação. No momento, três casos nos preocupam profundamente. O primeiro é o do Colégio Pedro II na cidade do Rio de Janeiro. Lá, professores de História, há alguns meses, foram interpelados pelo Ministério Público Federal, que acaba de abrir um processo administrativo contra esses servidores públicos federais por supostos delitos. O segundo é o processo civil contra a professora Marlene de Faveri no Estado de Santa Catarina, por suposta propaganda do feminismo em sua atividade docente. E, finalmente, o afastamento da atividade docente do Professor José Mineiro da rede pública estadual do Rio Grande do Sul, em função também do conteúdo de sua atividade docente. Todos esses eventos de censura e perseguição a professores são baseados principalmente na "crença" do "Escola sem Partido" de que os docentes estariam fazendo "doutrinação esquerdista" dos seus alunos. A ANPUH registra sua indignação com a desvalorização e a criminalização do trabalho dos profissionais da História presentes nesse tipo de ação e chama a atenção para os resultados catastróficos para o futuro da democracia e do pensamento crítico e emancipador na sociedade brasileira. (ANPUH, 2017)

Marduk: Não adianta chorar petralhada: acabou a farra. Ninguém mais vai doutrinar nossas crianças para o comunismo... Chega de professor pregando ideologia de esquerda. Vamos limpar o brasil dessa escória...

Adolf: Fora porcos comunistas. Deixem nossas crianças em paz.

Vai com as outras: Concordo plenamente com a Escola Sem Partido. Escola deve e tem que ser apartidária.

O desconforto físico retorna, acompanhado agora de uma forte náusea. Ela sabe o que vai acontecer. Demokratia.br corre, tropeça no tapete da sala, levanta-se e cambaleante abre a porta do banheiro: enfim a privada, o vômito, uma breve sensação de alívio. Acho que vou me deitar 
um pouco. Sim, vai me fazer bem. Ao encostar o rosto no travesseiro Demokratia.br experimenta o gesto plastificado do controle remoto da TV acariciando sua testa. Com ele em mãos, agora, Play:

De acordo com o ex-ministro da Cultura, Geddel o procurou pelo menos cinco vezes para que o Iphan, órgão subordinado ao Ministério da Cultura, aprovasse um projeto imobiliário de seu interesse. (...) Com apartamentos avaliados em 2,6 milhões de reais, o La Vue foi projetado para ter 30 andares, uma altura que destoaria do restante da região e descaracterizaria o local. Por conta disso, em 2014 o projeto recebeu parecer contrário do Escritório Técnico de Licenciamento e Fiscalização de Salvador (Etelf) (Carta Capital, 2016)

Não quero vomitar de novo. Por que isso não para? Demokratia.br tenta mudar de canal:

O Senado aprovou nesta terça-feira (13/12), em segundo turno, a PEC do teto dos gastos (PEC 55) por 53 a 16 votos, que congela por 20 anos os gastos do Estado brasileiro. Um destaque apresentado pela oposição, que garantia a continuidade da política de valorização do salário mínimo ao atrelar o reajuste do vencimento ao crescimento do PIB, foi rejeitado por 52 votos a 20 pelos senadores. Com a PEC, portanto, os salários mínimos podem ficar sem reajuste pelos próximos 20 anos. Outro destaque, que excluía do congelamento os investimentos em saúde e educação e mantinha as vinculações constitucionais para as áreas, também foi rejeitado por 52 a 19. A PEC deve ser promulgada pelo Congresso no próximo dia 15. (Fiocruz, 2016)

O controle remoto parou de funcionar. Uma batidinha, duas. Nada. O canal permanece o mesmo. Demokratia.br se levanta, vai em direção ao aparelho, mas todos os botões estão emperrados. Sente-se enojada, gostaria de desligar a programação. Puxa a tomada do aparelho na rede elétrica e então perplexa, sem compreender como, a programação continua sendo transmitida:

(...) Se você fizer os 25 anos de contribuição e fizer 65 anos idade, você já parte de $76 \%$. Portanto, se você cumprir estes dois requisitos você já tem $76 \%$ de aposentadoria. Mas se você começou com 20 anos e contribuiu durante 45 anos, você tem, na verdade, $96 \%$ de aposentadoria. Se você trabalhou 50 anos, você tem $100 \%$ de aposentadoria. (Temer, 2017)

Demokratia.br sente-se enojada, gostaria de desligar a programação. Como o controle remoto parou de funcionar e os botões da tv estão emperrados não lhes resta muita alternativa. Procura a tomada do aparelho na rede elétrica e a desconecta. Perplexa, sem compreender como, Demokratia.br é invadida pela programação que continua sendo transmitida:

Aécio Neves: Oi, Gilmar. Alô.

Gilmar Mendes: Oi, tudo bem?

Revista do Instituto Histórico e Geográfico do Pará (IHGP), (ISSN: 2359-0831 - online), Belém, v. 04, n. 02, p. 67-87, jul./dez. 2017. 
Aécio: Você sabe um telefone que você poderia dar que me ajudaria na condução lá. Não sei como é sua relação com ele, mas ponderando... Enfim, ao final dizendo que me acompanhe lá, que era importante...

Era o Flexa, viu? [Aécio se referia ao senador Flexa Ribeiro]

Gilmar: O Flexa, tá bom, eu falo com ele.

Aécio: Porque ele é o outro titular da comissão, somos três, sabe?... Né...

Gilmar: Tá bom, tá bom. Eu vou falar com ele. Eu falei... Eu falei com o Anastasia e falei com o Tasso...

Tasso não é da comissão, mas o Anastasia... O Anastasia disse "Ah, tô tentando...

Aécio: Se pudesse ligar para o Flexa aí e fala...

Gilmar: Eu falo pra com ele... E falo com ele... Eu ligo pra ele... Eu ligo pra ele agora. (Globo, 2017)

Irritada, Demokrátia.br procura algo para lançar sobre o aparelho de TV. Almofadas, cobertores e travesseiros apenas acariciam a Tela tenebrosa. Demokratia.br abre a geladeira e passa a jogar sobre o aparelho tudo que vem a sua mão: ovos, cubos de gelo, meia garrafa de vinho, pote de margarina. Nada. A maldita programação insiste:

Neste último domingo, dia 10 de setembro de 2017, um novo dissenso emergiu nas redes sociais brasileiras após o cancelamento da exposição Queermuseu - cartografias da diferença na arte da brasileira. A mostra, que reunia 270 trabalhos de 85 artistas - dentre os quais constam Adriana Varejão, Alfredo Volpi, Alair Gomes, Candido Portinari, Flávio de Carvalho e Ligia Clark, todos reconhecidos e celebrados para além das fronteiras nacionais, em virtude da relevância de sua produção artística -, deveria estar aberta ao público entre os dias 15 de agosto e 8 de outubro, mas foi encerrada pelos responsáveis do espaço Santander Cultural após protestos promovidos pela sociedade civil e alguns grupos organizados, entre eles associações religiosas e o MBL (Movimento Brasil Livre). (Barros et al, 2017)

Num surto de cólera Demokratia.br arremessa o aparelho no chão, faíscas, choque elétrico, fumaça, perigo. Assustada Demokratia empurra a geladeira sobre o que ainda restava do aparelho de TV despedaçando-o completamente.

Silêncio.

Será que acabou? Ela se aproxima dos escombros. Meio kilo de alcatra e três fatias de mortadela se misturam aos transistores abalados pela queda. Com a ponta do pé esquerdo ela toca nos cacos de vidro espalhados pelo chão. De repente, sem pedir passagem uma voz fantasmagórica emerge dos restos de carne bovina:

\section{TEM QUE MANTER ISSO AÍ, VIU?}

Será que estou enlouquecendo? Isso não é possível. O que está acontecendo comigo? Soluço. Choro. Preciso fazer alguma coisa. Será que um psicólogo poderia me ajudar? Acho que 
havia um cartão por aqui ... procura pela casa, nada. Talvez na internet. Confusa, Demokratia.br, parte em busca do que consegue digitar em seu navegador: intervenção psicológica. O buscador direciona a pesquisa para várias fanpages. Numa segunda busca, apressada, Demokratia.br aperta o botão enter antes de escrever psicológica e recebe como retorno centenas de fanpages “exigindo” uma Intervenção Militar no Brasil. Demokratia.br fecha, delicadamente, suas mãos, busca pelos sentidos. A visão está turva, a boca seca, observa suas mãos abrindo-as lentamente, náusea, tontura. Com o dorso das mãos tocando, agora, seu rosto busca por uma instabilidade longínqua. Tudo indica que a experiência de um colapso esteja muito próxima. Em meio ao pensamento deste breakdown alguém bate a porta. Demokratia.br da Silva recebe a visita de dois amigos que respiram numa velocidade outra. Que carregam cada conceito com uma rigorosidade explosiva. Amigos cuja companhia exige um demorar-se, um ainda não, uma espécie de silêncio, fissura, vacúolo à frenética comunicação contemporânea.

\section{UMA VISITA DE DELEUZE OU O ESGOTAMENTO DO POSSÍVEL}

À esquerda, que perde a esperança do possível, Deleuze parece dizer: muito bem que haja o esgotamento

do possível Zourabichvili

Demokratia.br - mas que surpresa ... que alento encontrar-me com o sorriso de vocês...

Francisco Varela - Viemos ver o que está acontecendo contigo. Tem gente falando em colapso... achamos curioso...

Gilles Deleuze - Comment ça va, Demokratia.br?

Demokratia.br - nada bem queridos...vertigem, nojo; acho que cheguei no meu limite (...) esgotada...devo estar esgotada. É como se os muros a minha frente estivessem sem fissuras. 
Muros intransponíveis. Me sinto sem forças. Por todo o lado, o solo no qual tento me sustentar, afunda. Me sinto sufocada. Preciso de um possível, Deleuze. O possível, senão sufoco.

Deleuze - (Gargalhada Rouca). Não viemos aqui oferecer compaixão, Demokratia.br. Uma coisa é estares cansada, outra bem diferente é o esgotamento.

Demokratia.br - (Como que pega em flagrante, tentando se recompor) Não sei se compreendo a diferença...

Deleuze - O cansado é aquele que não dispõe mais de qualquer possibilidade (subjetiva) - não

pode, portanto, realizar a mínima possibilidade (objetiva). Mas esta permanece, porque nunca se realiza todo o possível; ele é até mesmo criado à medida que é realizado. O cansado apenas esgotou a realização, enquanto o esgotado esgota todo o possível. O cansado não pode mais realizar, mas o esgotado não pode mais possibilitar. (DELEUZE, 2010, p.67)

Demokratia.br - Então, o cansado é aquele que deixa de realizar algo (uma possibilidade) dentro de um campo de possível já aberto. É isso?

Deleuze - Exatamente! Deus é o originário ou o conjunto de toda possibilidade. (...) quando se realiza um possível, é em função de certos objetivos, projetos e preferências: calço sapatos para sair e chinelos para ficar em casa (...) A linguagem enuncia o possível, mas o faz preparando-o para uma realização. (...) a realização do possível procede sempre por exclusão, pois ela supõe preferências e objetivos que variam, sempre substituindo os precedentes. São essas variações, essas substituições, todas essas disjunções exclusivas (a noite/o dia, sair /voltar ... ) que acabam cansando. (DELEUZE, 2010, p.68 e 69)

Demokratia.br - Certo! Então, quando você disse "um pouco de possível, senão eu sufoco" (Deleuze, p.246, 2016) estava se referindo a realização de uma possibilidade que o seu cansaço impedia?

Deleuze - Não, não, não...(devir tose em meio a gargalhada rouca). Felix e eu não nos referimos ao possível da possibilidade - pré-existente, lugar a se chegar, meta a conquistar - mas sim ao possível da potência, aberto pelo/no encontro. Aberto pelo acontecimento maio de 68. Quando 
enunciamos a coisa desse modo eu estava trabalhando com a fórmula de Bartleby - preferiria não - e ao mesmo tempo me preparando para escrever um ensaio sobre o teatro de Beckett - O Esgotado. Esperava criar, um paradoxo entre os dois mundos. Desejava aproximar-me de uma política onde se poderia esgotar o possível da possibilidade - tal qual o fazem as três línguas no teatro de Beckett - para se encontrar com o possível da potência. Uma política onde ao esgotar a meta final, a realização do possível, criaríamos condições de possibilidade para a abertura da potência, do acontecimento. Estava em busca da potência do possível e não da realização de algo previamente aberto. Minha questão, de uma certa forma, acho que de Felix também, sempre esteve atravessada pelos devires revolucionários.

Demokratia.br - Ummmm... Possivelmente meu corpo esteja cansado, então. Há tantas coisas que preciso fazer...tantas...mas como seguir em frente se me impedem de realizar meus possíveis? Isso tudo é muito cansativo. Todo esse ódio. Essas pessoas me odeiam, Deleuze. Elas mataram minha mãe e agora querem me destruir também...

Deleuze - Novamente você choraminga pedindo compaixão. Achas que Rancière apreciaria a utilização disso que fazes do trabalho dele ${ }^{3}$ Você está tão colada a realização dos possíveis que acaba se confundindo com uma forma de Estado, e mesmo de governabilidade. Há um princípio anárquico, constituindo teu corpo, que essa confusão impede de ver: a igualdade. Rancière explica que a tecnologia utilizada na grécia antiga para fazer valer a democracia era o sorteio. Pois se tratava do governo do "qualquer um" em oposição ao governo dos bem nascidos e ou dos ricos. Ao se confundir com uma forma de governabilidade você não leva em conta que as forças oligárquicas estão sempre presentes no Estado e acaba choramingando como uma democracia burguesa, constitucional, bem comportada, boa para todos, enfim, traída pelos que juraram te amar e proteger. Essa utopia, essa democracia dos bem intencionados legisladores, dos jornalões apressados e da sociedade de comunicação é que te exige cumprimento de metas, realização de

\footnotetext{
${ }^{3}$ Rancière, Jaques (2014). O ódio a democracia. Trad. Mariana Echalar. São Paulo: Boitempo. Revista do Instituto Histórico e Geográfico do Pará (IHGP), (ISSN: 2359-0831 - online), Belém, v. 04, n. 02, p. 67-87, jul./dez. 2017.
} 
possíveis. Ao invés de choramingar pelos cantos em busca de olhares piedosos não seria mais coerente com sua história potencializar as forças que constituem teu corpo?

Demokratia.br - Ah, meu amigo...(soluço) como me fortalecer se não posso realizar meus possíveis? Se impedem minha força de agir no governo de uma presidenta que foi eleita pela grande maioria; se me proíbem de realizar uma aula ou uma exposição de arte contemporânea cujas temáticas possuem relação política direta com minhas entranhas; se me tomam como instrumento de locupletação individual e por isso interrompem a realização de uma cidade; se meus ossos se transformam em ferramentas para realizar cada vez menos uma educação, uma saúde e uma segurança pública; se me impedem de realizar a aposentadoria de milhões de brasileiros... (respiração profunda) Talvez, meu amigo, o que esteja em curso seja o fortalecimento de outros corpos políticos: fascistas, autocráticos, ditatoriais.

Deleuze - Você está mesmo cansada, Demokratia.br. Tudo que consegues enunciar parece atravessado pela realização dos possíveis: teus afectos experimentam uma constante e terrível dicotomia: ou isso ou aquilo. Teu corpo foi capturado pelas disjunções exclusivas... Mas que Diabos! Onde estão tuas potências?

(Silêncio)

Demokratia.br - Não sei, meu querido. Eu gostaria de ter forças para invadir, novamente, o Estado Oligárquico como temos feito, minha família e eu, ao longo da história republicana do Brasil. Embora nessa forma representativa, acabamos, sempre, de um modo ou de outro trazendo de volta ao poder as oligarquias transformando o governo do "qualquer um" no governo dos supostamente melhores, pois escolhidos pela maioria. Talvez isso que você nominou choramingo seja uma forma de evitar esse sentimento de culpa. Um modo de disfarçar. De esquecer que vivemos em um estado de direito oligárquico, onde predomina uma aliança entre a oligarquia estatal e a econômica. (Rancière, 2014). Na verdade eu gostaria mesmo era de trazer de volta ao jogo o público em forma de polêmica. De me apresentar “(...) como atividade pública que 
contraria a tendência de todo Estado de monopolizar e despolitizar a esfera comum?" (Rancière, p.92, 2014)

Deleuze - Ótimo! se acabou o chorare ${ }^{4}$...poderias aproveitar para enfrentar, também, o problema político dos possíveis... (gargalhada rouca)

Demokratia.br - Ai, Deleuze. Gosto tanto de ti, nunca te disse isso.... Mas hoje preciso falar: na maioria das vezes, tenho dificuldades para compreender o teu pensamento político. Pronto, falei...

Deleuze - Dificuldades? (tocando de leve na aba do chapéu). Não estarias, mais uma vez, buscando realizar um possível? (Ironicorrouca risada amarela)

Demokratia.br - Ah, Gilles. Por favor. Você se diz um pensador de esquerda e ao mesmo tempo passa a vida ridicularizando o voluntarismo em termos políticos. ${ }^{5}$ Como entender isso?

Deleuze - (ataque de gargalhosse) - sim, isso está correto. Nas proposições 48 e 49 da segunda parte da Ética Espinoza também o faz.

Demokratia.br - Nunca compreendi onde você pretende chegar com essa crítica. Você sabe bem que “(...) a esquerda, não importa de que natureza seja, define-se geralmente pelo seu voluntarismo" (ZOURABICHVILI, 2000, p.333)

Deleuze - Ah! Quanto a isto não posso estar de acordo. Restringir a ação política a volição - e por consequência aos pressupostos da autonomia, emancipação e livre contrato - não define a

\footnotetext{
${ }^{4}$ Novos Baianos.

${ }^{5}$ voluntarismo (do lat. voluntarius) 1 . Concepção filosófica que atribui à *vontade um papel central, que supõe que tudo é fruto da vontade, embora isso seja interpretado de diferentes maneiras em diferentes correntes filosóficas. Segundo *Duns Scotus, uma vez que a *liberdade de *Deus é o princípio de todas as coisas, aquilo que é verdadeiro ou bom depende, em última análise, da livre determinação da vontade divina. (Japiassu e Marcondes, 2001, p.189).

É claro que a esquerda não acredita mais em projetos. Tendo, no entanto, se identificado com a realização de projetos, ela não tem, ao que parece, outra escolha senão renunciar a si mesma ou tentar ainda acreditar naquilo em que não mais acredita: renegar ou negar. De forma, que o voluntarismo não concerne mais, aqui, a ação, e sim a crença na ação. (Zourabichvili, 2000, p.333, 334)
}

Desde un punto de vista político sí hay una linea discriminatória entre marxistas y no marxistas. El reconocimento de la lucha de classes y la prioridad de la organizacion autonoma - social y política de las classes trabajadoras. Creemos que este marxismo debe caracterizarse por un fuerte realismo sociológico (para evitar los trágicos errores a que conduce el dogmatismo y el vanguardismo) y por un decidido voluntarismo político (porque si él no hay processos de organización, lucha y cambio.) (Jordi Borja, 1985, p.194).

Revista do Instituto Histórico e Geográfico do Pará (IHGP), (ISSN: 2359-0831 - online), Belém, v. 04, n. 02, p. 67-87, jul./dez. 2017. 
esquerda, mas sim esse pensamento mole dos direitos humanos, do jornalismo, da sociedade de informação onde todos são chamados, como tagarelas, a darem suas opiniões. Uma esquerda que faz da vontade do sujeito a origem de suas ações, escolhas, opiniões é uma esquerda medíocre e merece entrar em colapso. Mais que isso, devemos ajudar a colapsar-la. Em as Palavras e as Coisas Foucault já o sabia: a morte de deus matou também o homem. Como se poderia continuar acreditando no homem, numa vontade do homem como pressuposto de sua emancipação? Ah, dirão alguns, mas não se trata mais daquela categoria ingênua fabricada pelo cogito descartiano, tão comemorada pelo humanismo. A vontade que consideramos revolucionária, base de nossa ética, não estaria propriamente no cogito/homem, mas sim num transcendente a moda de Kant. A categoria que sustenta nosso pressuposto político, que nos permite lutar pela emancipação e autonomia dos seres humanos é o sujeito e não mais o eu. Cabendo a esse sujeito emancipar-se através da lei, do contrato, da obediência às legislações. Pois bem, da mesma forma, caberia perguntar: que volição seria essa se o sujeito não passa de um efeito do poder. (FOUCAULT, 2007). Homem, sujeito, psique, alma, dêem o nome que quiserem. Pois "esta alma real e incorpórea não é absolutamente substância; é o elemento onde se articulam os efeitos de um certo tipo de poder e a referência de um saber, a engrenagem pela qual as relações de poder dão lugar a um saber possível, e o saber reconduz e reforça os efeitos de poder. Sobre essa realidadereferência, vários conceitos foram construídos e campos de análise foram demarcados: psique, subjetividade, personalidade, consciência, etc.; sobre ela técnicas e discursos científicos foram edificados; a partir dela, valorizaram-se as reivindicações morais do humanismo. Mas não devemos nos enganar: a alma, ilusão dos teólogos, não foi substituída por um homem real, objeto de saber, de reflexão filosófica ou de intervenção técnica. O homem de que nos falam e que nos convidam a liberar já é em si mesmo o efeito de uma sujeição bem mais profunda que ele. Uma "alma" o habita e o leva à existência, que é ela mesma uma peça no domínio exercido pelo poder sobre o corpo. A alma, efeito e instrumento de uma anatomia política; a alma, prisão do corpo. (FOUCAULT, 2007, p. 27 e 28 
Demokratia.br - Bem, você está querendo dizer que se o corpo está aprisionado por uma ideia de alma/sujeito/subjetividadesempre que creditamos a origem da vontade ao sujeito - e isso com as melhores das intenções político/emancipatórias - estamos fortalecendo com nosso voluntarismo bem intencionado as grades que aprisionam este corpo numa ficção contratual/legalista?

Deleuze - O corpo - político e/ou fisiológico e/ou sem órgãos- estará sempre agenciado por uma ficção. Estamos num campo onde não há verdades essenciais a serem descobertas. A questão é que a ficção, em específico, que estamos debatendo - o homem - encontra na morte de deus sua

origem e destruição. Trata-se de ter coragem e avançar para um pensamento onde a ação política não necessite mais de uma âncora/origem divina-humana. Onde possamos abandonar as leis e nos aproximarmos das instituições. "Tal teoria nos dará, enfim, critérios políticos: a tirania é um regime onde há muitas leis e poucas instituições, a democracia é um regime onde há muitas instituições e muito poucas leis. A opressão se mostra quando as leis são aplicadas diretamente sobre os homens, e não sobre as instituições prévias que garantem os homens" (Deleuze, p.21, 2005)

Demokrátia.br - Achas que avançar nesse sentido abriria condições de possibilidade para produzir exercícios de poder onde aqueles que não tem razão, ou títulos, para governar - seja em nome do nascimento, da idade, do capital ou da ciência - governem os que não tem razão para serem governados? Trata-se, então, de dar poder àqueles que não têm títulos de poder?

Deleuze - Compreendo tua leitura de Rancière (2014). Mas guardo algumas diferenças. O exercício político, para mim, passa por uma ética o menos voluntarista possível, onde reivindico a 'má vontade' do idiota à moda russa, o 'nada de vontade' do original à americana. (ZOURABICHVILI, 2000)

Demokratia.br - É por isso que você insiste tanto no carácter profundamente involuntário de todo verdadeiro pensamento, de todo devir?

Deleuze - Oui! 
Demokratia.br - Acho que começo a enteder. Da mesma forma, é por isso que você ridiculariza os projetos de transformação do mundo que seguem um plano, uma função, uma meta. Ao mesmo tempo que você não cessa de celebrar, de espreitar, ou, na ocasião oportuna, de acompanhar o que gosta de chamar de 'devires-revolucionários' (ZOURABICHVILI, 2000).

Deleuze - Sim, sim (tosse rouca em devir sorriso). Pois me parece que o que nos sufoca é o excesso de realizações, o que nos sufoca é a opressão do já estabelecido, de sermos arrastados a um permanente escolher entre esta ou aquela opção previamente definidas como se algo dentro de nós - alma, sujeito, subjetividade - respondesse em uma condição de livre-arbítrio à uma lei que deve ser seguida, depositando sobre o sujeito uma responsabilização individual por suas escolhas.

Demokratia.br - Talvez o funcionamento do que Rancière (2014) chamou de Estado Oligárquico encontre neste jogo sua realização. Já que se trata de governar através de uma democracia representativa, onde todos são obrigados a escolher entre esta ou aquela opção. Ou seja, a opção de escolha é dada diante de uma lei que assegura às elites o mais alto grau de representatividade. Permitindo que supostamente governem em nome do povo, desde que não haja participação direta desse.

Deleuze - Como esgotar, portanto, o conjunto desse possível? Abrir um possível como potência: criar um acontecimento, colocar-se à disposição dos devires revolucionários? Dizendo de outro modo, se fazer política é um fazer coletivo - ainda que muitas vezes de um coletivo em nós - este fazer necessita estar aberto ou mesmo realizado para além do primado do sujeito, na ampliação da dimensão pública. Enquanto o corpo político da democracia permanecer refém de uma filosofia voluntarista, contratual e representativa continuaremos soterrados pela náusea. Ou seja, nossa problemática política é ao mesmo tempo uma questão ética. Trata-se de esgotar, no exercício político, o possível da possibilidade para criar condições de abertura ao possível da potência. 


\section{UMA VISITA DE FRANCISCO VARELA OU A EXPERIÊNCIA ÉTICA}

Se um afeto está referido a muitas diferentes causas, as quais a mente considera ao mesmo tempo que o próprio afeto, ele é menos nocivo,

padecemos menos em virtude dele e somos menos afetados por cada uma de suas causas, comparativamente a um outro afeto, tão forte quanto ao primeiro mas que está referido a uma única causa ou a um número menor de causas.

Demokratia.br - Talvez meu grande medo seja o de abrir meu corpo para a diferença, para os micromundos, e acabar caindo num niilismo sem fim, num relativismo extremo. Como fortalecer meu corpo, como não fragiliza-lo ainda mais? Essa conversa contigo Gilles me fez lembrar de um encontro com Francisco onde pensamos, o exercício ético distinto da proposição moral. Você lembra disso?

Varela - Sim! Lembro. Foi quando tomamos a Ética como uma palavra muitas vezes proferida. Mas que em seu uso cotidiano, aparece quase sempre vinculada a ideia de moral.

Demokratia.br - É uma situação muito engraçada! Quando a moral invade meu corpo, acabo sendo usada como regra, lei, regimento. E assim todos passam a me defender. Quando gritavam, aos milhões, "Fora Dilma" era em minha defesa que marchavam. Mas do mesmo modo quando gritavam "Fica Dilma" também era. Tem coxinha, tem petralha; tem gente nas ruas de verde e amarelo, tem gente de vermelho. Tem muito comunista, mas também tem muito liberal. Todos marchando em minha defesa. O jogo identitário/contratual me transforma em uma espécie de norma universalmente boa. Nada mais justo, portanto, que eu seja defendida por todos... Isso tudo é tão estranho...

Varela - Talvez tenhamos que nos perguntar de que democracia se trata, afinal, diante de defesas, quase sempre, apaixonadas que acreditam proteger teu corpo. Já que na maioria das vezes 
defendem uma moral que acaba usurpando o corpo destes que se acreditam teus defensores, algo bem distinto de uma experiência ética.

Demokratia.br - Na obra de Rancière (2014) que debatia a pouco com Gilles há uma hipótese sobre como o caminho ético foi sendo moralizado. Ele diz que a vitalidade democrática, na antiguidade grega, foi tomando duas formas: “(...) ou a vida democrática significava uma ampla participação popular na discussão dos negócios públicos, e isso era ruim, ou significava uma forma de vida social que direcionava as energias para as satisfações individuais, e isso também era ruim. A boa democracia deveria ser então uma forma de atividade e de vida social capaz de controlar o duplo excesso de atividade coletiva ou de retração individual inerente à vida democrática" (p. 17)

Varela - Sim, a ética é um cultivo, dentro de um marco não moralista. Se aproxima muito mais da sabedoria do que da razão ou de um juízo. A valorização do juízo moral, que divide o bom e o mau, os pró e os contra, tornou a ação ética um reflexo do primeiro. Tudo se passaria como se o juízo moral balizasse necessariamente a ação. Trata-se, entretanto, de produzir uma inversão: Por que não iniciar com aquilo que é mais cotidiano - nossa ação - e ver onde ela nos leva?

Demokratia.br - Não compreendo o que queres dizer com mais cotidiano...

Varela - Ok! Vou utilizar uma cena: “(...) chegamos ao escritório e, apercebendo-nos do embaraço da secretária sobre uma dada questão, mudamos a conversa com um giro humorístico. Ações como esta não derivam de juízos ou de raciocínios, mas de um confronto imediato com os acontecimentos que nos sobrevêm. Podemos apenas dizer que realizamos essas ações porque a própria situação as faz emergir do nosso íntimo. Não obstante, elas são verdadeiras e genuínas ações éticas, representam efetivamente o tipo mais comum de comportamento ético que manifestamos na nossa vida normal cotidiana" (VARELA, 1992, p.15). Com isso busco distinguir entre uma prontidão para a ação (saber-fazer) e o juízo intencional, racional (saber-oque). Você me pergunta como sair das dicotomias, mas essa questão ainda se encontra no plano do juízo. As disposições para a ação que potencializam o exercício ético são fruto de um cultivo. 
Não se trata de adicionar retidão a seus atos. Encarnamos a ética e quando isso acontece, ela produz um comum, a interface - a dobradiça - que liga os micromundos. Mas, insisto no cultivo, a criação não se produz de modo espontaneísta. No momento que o exercício ético produz um entre, um comum, nos potencializa e ressoa com aqueles com os quais compartilhamos os micromundos.

Demokratia.br - Deixa ver se estou entendendo: você quer dizer que os colapsos sinalizam uma oportunidade de conexão de produzir dobradiças entre os micromundos?

Varela - Exatamente. Os breakdowns ou "as perturbações são eixos que articulam os micromundos, que constituem a fonte do lado autônomo e criativo da cognição viva. Importa, pois, examinar tal sentido comum numa microescala, pois é nos momentos durante a perturbação que se realiza o nascimento do concreto" (VARELA, 1992, p. 21). Ao mesmo tempo, seria possível dizer, que experimentamos um colapso quando nos transformamos corporalmente diante de um encontro perturbador.

Demokratia.br - E nesse sentido é que você define a ética como criação?

Varela - Claro. Pois um exercício ético se diferencia do uso dos esquemas habituais ou regras. As respostas meramente habituais não têm suficiente diversidade para dar conta da multiplicidade de encontros que nos acontecem. Trata-se da mera realização dos possíveis, como conversavas com Deleuze. Por isso, a conduta ética pode mesmo chegar a parecer uma "sabedoria louca" (crazy wisdom, VARELA, 1992), por ser criação, por ser um possível da potência. Tal como o exercício anárquico do sorteio que operava a igualdade na Grécia antiga. Podemos considerá-lo como uma prática ética. Em nossos tempos pode ser considerada uma sabedoria louca porque reinventaria a nós mesmos e os micromundos em que vivemos, produzindo uma diferença em relação ao que estávamos habituados.

Demokratia.br - Adorei essa tal de Sabedoria Louca. Me fez lembrar aquela vez que você tentava me convencer de que seria possível distinguir, a partir dos ensinamentos de Menz Tzu, a virtude e a honestidade. 
Varela - Ótima dobradiça (gargalhadas).

Demokratia.br - Obrigada. Acho que ela faz dobra com o plano dos acontecimentos que estou vivendo...

Varela - Como assim?

Demokratia.br - As vezes sinto como se meu corpo estivesse dobradiçalhado as duas terapeuticas que me foram receitadas como tratamento à minha doença ético/política. Terapias para governar o ingovernável. Esse médico aqui (mostrando a receita) foi categórico: apenas uma grande limpeza pode me curar. O tratamento prevê delações premiadas e provas fabricadas numa tentativa de me desintoxicar completamente da corrupção. Para isso acredita que seria preciso expurgar várias pessoas da cena política, no sentido de moralizar, pressionar, dar exemplo àqueles que usaram a máquina pública para se perpetuar no poder.

Varela - Que curioso (observando a receita) E o outro tratamento?

Demokratia.br - Bem, esse aqui (mostrando a segunda receita) me prescreveu uma reforma política. O diagnóstico dele é de que o jogo como está precisa ser repensado em suas regras e acordos, de modo que seja possível jogar sem cair nas malhas dos investidores de campanhas, das pressões e conchavos partidários na aprovação ou não de leis. Achas que esses tratamentos poderiam me ajudar?

Varela - Hmmm! Uma receita deve ser posta em análise a partir das forças que enlaça em sua efetuação. Essa é uma atitude que implica questões éticas. . Acompanhar seu processo, sua posta em marcha. Observamos, ao longo da história, a medida que o "governo dos melhores" é fortalecido pelas oligarquias vai substituindo o governo do "qualquer um".

Demokratica.br - Puxa, Francisco. Então se entendi, você está dizendo que a questão principal é o modo como se vive a ética em uma cultura, política, ou melhor, em um cotidiano. A questão seria perceber os momentos pelos quais a ética se transforma em moral e reconfigura a vida, a experiência? 
Varela - "A ética para mim é um terreno novo". O que disse pra ti, "deve sobretudo tomar-se no espírito de uma aventura". "Já que o que fiz foi cultivá-la num ângulo não moralista para pensar o nosso confuso e desorientado mundo contemporâneo" (VARELA, 1992, p. 12). A minha argumentação "é, mais do que qualquer coisa, uma proposta para um reencantamento da sabedoria, entendida como ação não-intencional. Este saber viver baseia-se numa pragmática de transformação, a qual nada mais requer do que uma consciência, momento a momento, da natureza virtual de nós próprios. No seu pleno desabrochar, patenteia uma abertura mental entendida como autêntico cuidar de si. Eis algumas ideias radicais e medidas drásticas para os tempos agitados que estamos a viver e para os ainda mais difíceis que, provavelmente, teremos de enfrentar". (VARELA, 2003, p. 78)

\section{O CORPO QUE VEM}

\begin{abstract}
(...) é justamente nesse terreno incerto, nessa zona opaca de indiferenciação que hoje devemos encontrar o caminho de uma outra política, de um outro corpo e de uma outra palavra.
\end{abstract}

Agamben

Ao se despedir dos amigos nossa protagonista percebe em si o desejo de caminhar. Um feixe de forças perpassam seu corpo. As visitas de Deleuze e Varela impelem ao pensamento. Este exercício de ruminação dos visitantes agenciado ao deslocamento de si encontra em Nietzsche (1995) um refrão: Torna-te o que tu és; e em Agamben (2016) uma espécie de vida que vem. Demokratia.br se pergunta se estaria em devir uma política, um corpo e uma palavra capazes de escapar às formas identitárias. Não estaria aí, precisamente neste ponto, a dobradiça do seu sofrimento? Ou seja, não seria patológica a tentativa de conservar-se no possível, agarrando-se às realizações, conforme lhe provocou Deleuze? Como manter um cuidado, um cultivo - no sentido trazido por Francisco -, sem reforçar tais realizações, sem buscar mais 
polícia, mais justiça, mais propriedade, mais fascismo? Como permitir ao corpo democrático movimentos constantes, de subjetivação e desubjetivação? Que difícil, Demokratia.br implica-se a passos largos. Seria necessário, por certo, uma prática e não um princípio... Ela lembra, então, da ocupação de centenas de escolas e universidades iniciada em São Paulo, pelos estudantes secundaristas como protesto à proposta de reorganização da educação básica do governo Alckmin. Ocupações que se espalharam pelo país em um processo viral em 2016. Para além de um protesto com focos específicos, tornou-se uma experiência grávida de virtuais. Práticas autogestionadas que ensinaram mais do que muitos anos escolares. Práticas que não reivindicavam um direito de uso, mas um uso sem direito: ocupar, abrir um território para outra experiência coletiva. Foram fabricados modos de ação e de afecção que problematizaram práticas constituídas da instituição educativa, como os processos de aprendizagem; as escolhas curriculares; as práticas de poder. Modos processuais e temporários. Nesses momentos de ruptura, ou de breakdown - reflete Demokratia.br - a criação não depende de uma decisão externa ou de um planejamento prévio. Trata-se da emergência de um comum que, ao se realizar, produz, no mesmo ato, um coletivo. Um corpo coletivo. Mas isso não passa por um processo de otimização, mais se parece com uma bifurcação ou ruptura de uma simetria em uma dinâmica caótica. A chave é a invenção (ou o possível da potência como Deleuze me dizia), as ações efetivas criadas surgem de seus próprios recursos. Pode-se-lhe criticar uma certa efemeridade, apesar de algumas ocupações se estenderem por vários meses, mas estamos longe de poder mapear os possíveis da potência que foram aí inventados. Demokratia.br sorri, finalmente, segue caminhando, mas ocupada agora por uma memória Primavera Árabe; Maio de 68; Movimento Verde; Occupy Wall Street; Los Indignados; Junho de 2013...

Nota: Agradecemos a leitura de Cláudia Abbês, pelas importantes contribuições a este ensaio. 


\section{REFERÊNCIAS}

AGAMBEN, G. Uma biopolítica menor. Série Pandemia. n-1edições.org. 2016.

ANPUH. Associação Nacional de História. Acessado em 21 de junho de 2017. Disponível em: https://site.anpuh.org/index.php/2015-01-20-00-01-55/noticias2/noticias-destaque/item/4050-nota-daanpuh-perseguicao-e-coacao.

BARROS, Juliana et al. Queermuseu: Os perigos da censura e do avanço conservador para a democracia. Revista Cult (online). Acessado em: 14 de setembro de 2017. Disponível em: https://revistacult.uol.com.br/home/queermuseu-censura-avanco-conservador-democracia/

CARTA CAPITAL. Parlatório, Política. Acessado em: 21 de novembro de 2016. Disponível em: https://www.cartacapital.com.br/blogs/parlatorio/geddel-vieira-lima-o-novo-enrosco-de-temer

DELEUZE, G. O Esgotado. Trad. Oenvídio de Abreu e Roberto Machado. In Gilles Deleuze: sobre o teatro. Rio de Janeiro: Jorge Zahar Ed, 2010.

. Maio de 68 não ocorreu. In Gilles Deleuze: Dois regimes de loucos: textos e entrevistas (19751995). São Paulo, Editora 34, 2016.

DELEUZE, Gilles; GUATTARI, Félix. O Anti Édipo: capitalismo e esquizofrenia. Trad. de Luiz B.L. Orlandi. São Paulo: Ed.34: 2010.

FIOCRUZ. Escola Politécnica de Saúde Joaquim Venâncio - Acessado em 15 de dezembro de 2016. Disponível em: http://www.epsjv.fiocruz.br/noticias/reportagem/senado-aprova-congelamento-dosinvestimentos-do-estado-por-20-anos.

FITZGERALD, F.S. O Colapso. In Fitzgerald: Crack Up. Trad. Rosaura Eichenberg. Porto Alegre: L\&PM, 2007.

FOLHA DE SÃO PAULO. Folha Digital, Poder. Jornal Folha de São Paulo: acesso em 23 de maio de 2016. Disponível em: http:/www1.folha.uol.com.br/poder/2016/05/1774018-em-dialogos-gravados-jucafala-em-pacto-para-deter-avanco-da-lava-jato.shtml

FOUCAULT, M. As Palavras e as Coisas: uma arqueologia das ciências humanas. Trad. de Salma Tannus Muchail. São Paulo, Martins Fontes, 1995.

.Vigiar e Punir: nascimento da prisão.Trad de Raquel Ramalhete. Petrópolis: Editora Vozes, 2007.

GLOBO. G1 Acessado em 19/05/2017. Disponível em:

https://g1.globo.com/politica/operacao-lava-jato/noticia/em-transcricao-de-audio-da-pf-aecio-pede-ajudaa-gilmar-mendes-sobre-lei-de-abuso-de-autoridade.ghtml

NIETZSCHE, Friedrich. Ecce Homo: como alguém se torna o que é. (Trad. Paulo Cesar de Souza). São Paulo: Companhia das Letras, 1995.

TEMER, Michel. Pronunciamento do Presidente Michel Temer. Vídeo: Youtube. Acessado em 01/03/2017. Disponível em: https://www.youtube.com/watch?v=yboaJlaoS0c.

Revista do Instituto Histórico e Geográfico do Pará (IHGP), (ISSN: 2359-0831 - online), Belém, v. 04, n. 02, p. 67-87, jul./dez. 2017. 


\section{Édio RANIERE; Cleci MARASCHIN}

SPINOZA, Baruch. Ética. Belo Horizonte: Editora Autêntica, 2007. Tradução Tomaz Tadeu da Silva. VARELA F. Ética y Acción. Santiago, Dolmen, 1996

VARELA, F. Sobre a competência ética. Lisboa: edições 70, 1992.

VARELA, F., THOMPSON, E.; ROSCH, E. A mente Incorporada: Ciências Cognitivas e Experiência Humana. Porto Alegre: Artmed, 2003.

ZOURABICHVILI, François. Deleuze e o possível (sobre o involuntarismo na política). In: ALLIEZ, Eric. Gilles Deleuze: uma vida filosófica. Trad. Ana Lúcia Oliveira. São Paulo: ed. 3, 2000, p 333- 355.

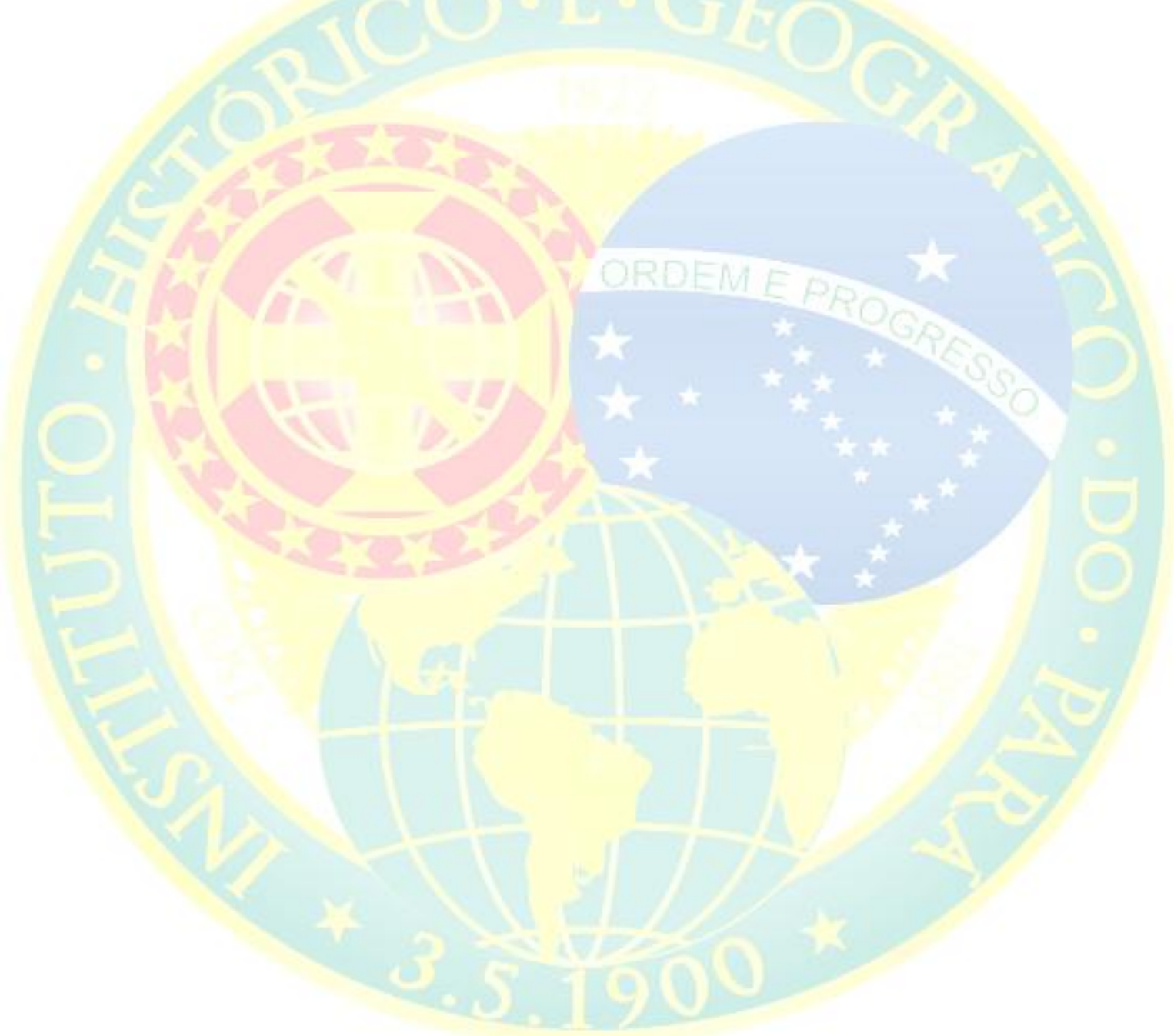

